\title{
Positive Politeness Principle In The Movie “The Last Song” By Nicholas Spark
}

\author{
I Made Andre Riana Putra ${ }^{1 *}$, I Nyoman Tri Ediwan ${ }^{2}$, I Komang Sumaryana ${ }^{3}$ \\ English Department, Faculty of Arts - Udayana University \\ ${ }^{1}$ [email: andre.riana64putra@gmail.com] ${ }^{2}$ [email: tri_ediwan@unud.ac.id] ${ }^{3}$ [email: \\ komangsumaryana@gmail.com] \\ *Corresponding Author
}

\begin{abstract}
The title of this study is Positive Politeness Principle in "The Last Song" movie by Nicholas Spark this study is aimed at finding out the positive politeness principle in romantic drama movie and tries to analyze kinds of politeness principle and discusses about the polite expression in terms of language function and factors of politeness principle that influence in positive politeness principle The Last Song movie. The analysis of this study concern with the utterances of Politeness Principle. The methods employed can be classified into four kinds: data source, method and technique of collecting data, method and technique of analyzing data and method and technique of presenting data. The data were collected of this research is started by watching a movie entitled The Last Song which is produced by Nicholas Sparks (2010), reading the script The Last Song movie and taking note in some parts of the conversation that related between the main characters and other characters of the movie which is shown the kinds of polite expression and factors that influence in politeness principle. The data was analyzed based on theory of politeness which proposed by Holmes (1992), Wardhaugh (1986) and Dell Hymes (1974). The results show of analyzing data, it is found that kind of politeness principle were applied by polite expression in terms of speech function were found in The Last Song movie that were expressive, directive, phatic, metalinguis, referential and poetic function. then the four factors that influenced in politeness principle were sex (gender), age, social status and education.
\end{abstract}

\section{Keywords: Positive Politeness, Politeness, Speech function, Movie}

\begin{abstract}
Abstrak
Judul penelitian ini adalah Prinsip Kesantunan Positif dalam film "The Last Song" karya Nicholas Spark. Penelitian ini bertujuan untuk mengetahui prinsip kesantunan positif dalam film drama romantis dan mencoba menganalisis jenis prinsip kesantunan dan membahas tentang persamaan sopan santun dalam istilah, fungsi bahasa dan faktor prinsip kesopanan yang berpengaruh pada prinsip kesantunan positif film The Last Song. Analisis penelitian ini berkaitan dengan ucapan Prinsip Kesantunan. Metode yang digunakan dapat diklasifikasikan menjadi empat macam: sumber data, metode dan teknik pengumpulan data, metode dan teknik analisis data dan metode dan teknik penyajian data. Data yang dikumpulkan dari penelitian ini diawali dengan menonton film berjudul The Last Song yang diproduksi oleh Nicholas Sparks (2010), membaca naskah film Last Song dan mencatat di beberapa bagian percakapan yang berhubungan antara karakter utama dan Karakter lain dari film yang diperlihatkan jenis ekspresi sopan dan faktor-faktor yang mempengaruhi prinsip kesopanan. Data dianalisis
\end{abstract}


berdasarkan teori kesopanan yang diajukan oleh Holmes (1992), Wardhaugh (1986) dan Dell Hymes (1974). Hasil penelitian menunjukkan analisis data, ditemukan bahwa jenis prinsip kesantunan diterapkan dengan ekspresi sopan dalam hal fungsi bicara ditemukan pada film The Last Song yang bersifat ekspresif, direktif, fatik, metalinguis, referensial dan fungsi puitis. Empat faktor yang mempengaruhi prinsip kesantunan adalah jenis kelamin (gender), umur, status sosial dan pendidikan.

\section{Kata kunci: Kesantunan positif, Kesantunan, Speech function, Film}

\section{Background of the Study}

As human beings, we know that communicating is an important thing and communication is one of human behaviors in society. It is used by people to do social interaction and communicate with one another. To build the good relationship among human beings we must learn the basic kind of ppoliteness. In daily life to know the kind of ppoliteness especially positive ppoliteness pprinciples, the positive politeness is the way how we express ourselves politely. It would give much impact on us.

Positive politeness is a strategy to minimize the threat to the hearer's positive face. They are used to make the hearer feel good about himself, their interest or to establish a positive relationship between parties. Direct speech acts, swearing and flouting grace's maxims can be considered aspects of positive politeness because they show an awareness that the relationship is strong enough to cope with. They articulate an awareness of the other person's values, which fulfill someone's desire to be accepted. ${ }^{1}$

The principles of positive politeness can be found in movies because movies sometimes represent daily life conversation between someone with another. Most movies are based on true stories. The sentences in the dialogue among the participants or characters in the movie "The Last Song" would be analyzed in order to get the appropriate way of showing politeness in the movie created by Nicholas Sparks as the author in the script.

${ }^{1}$ Holmes (1992), Wardhaugh (1986) and Dell Hymes (1974), Women, Men, Language (1995, New York: Longman).

\section{Problems of the Study}

The problems of study can be formulated as follows:

1. How do characters express politeness in terms of the principles of positive politeness in the movie "The Last Song"?

2. What factors contribute to the positive politeness in the movie "The Last Song"?

\section{Aims of the Study}

The aims of this study are as follows:

1. To describe the politeness expressions used by the characters to express positive politeness in the movie "The Last Song" movie.

2. To explain the factors those have contributed to the positive politeness used in the movie "The Last Song".

\section{Research Method}

Research method explains the way and how research is conducted.

\subsection{Data Source}

In this study the primary data were taken from the utterances in conversations among the characters in the movie "The Last Song" produced by Adam Shankman and Jennifer Gibgot, directed and written by Nicholas Spark. The movie was chosen as data source 
because it is very interesting and there are many conversations among the characters show many kinds of politeness.

\subsection{Method and Technique of Collecting Data \\ This study used the} documentation method to obtain the data. The process of collecting data was done by watching and listening to the conversations among the characters in the movie twice.

\subsection{Method and Technique of Analyzing Data}

The collected data in this study were analyzed qualitatively using the linguistic theories and the data were analyzed using the descriptive qualitative method. The technique of analyzing data was based on the theory of politeness proposed by Holmes (1992), Wardhaugh (1986) and Dell Hymes (1974).

\subsection{Method and Technique of Presenting the Result of Data Analysis}

The theory of politeness was used to analyze the positive politeness principles used in the movie "The Last Song" movie.

\section{Results and Discussion}

\subsection{Synopsis}

Estranged from her father for a number of years, teenager Ronnie isn't pleased when her mother ships her and her younger brother down to a Southern beach town to spend the summer with their father. While her father is using a shared love of music to try to reconnect with her, Ronnie finds romance with a handsome local man. Further, they are a perfect couple but in the end Ronnie realizes some message in her life.

\subsection{The Analysis of Politeness} Expression Based on Speech Function

The analysis of Positive Politeness is based on the speech function in the movie "The Last Song" by Nicholas Sparks and focuses on the utterances taken from the movie script or the sentences used by the main characters and other characters.

\subsubsection{Directive Function}

In the movie "The Last Song" with a background of the family situation, the conversation mostly reflects the politeness principles in the movie. In this case, directive functions include asking, suggesting, and commanding. The following conversation was taken from the movie script:

Mom : Stave.

Dad : How is she otherwise?

Mom : Well let's see.

In the conversation above there are some politeness expressions found based on the speech function. The personal conversation between Ronnie's mom and her dad used directive function. It clearly shows a suggestion. Dad suggests Ronnie's mom that she should take care of Ronnie.

\subsubsection{Expressive Function}

Expressive function is one of the ways in which the speaker expresses apologizing, agreeing, conceding, denying, welcoming, complaining, planning, thanking, complimenting, fighting, disproving, reprimanding, and consoling. From the conversation in the last song, the expressive function of Politeness can be seen in the conversation below.

Ronnie : Get out of my room! (Jonah reaction to his sister Ronnie with smile even his sister in mad situation)

Jonah : This is our room! ok? If you want to sleep in dad's room. (Ronnie let Jonah to sleep in her room, Ronnie 
rather choose another room, as older sister she respects to her brother.)

Ronnie : That's fine

From the dialogue above, Ronnie

as Jonah's older sister wants to sleep after she hangout with her new friends she is wondering and catches her brother asleep in her room. He applies complimenting and expresses his politeness with an utterance "Get out on my room".

\subsubsection{Poetic Function}

The poetic function can be defined as the use of language for the sake of the language use. The following utterance was taken from the movie script. It shows the politeness principle with the poetic function:

It's just so hard to feel happy in that house. It's the only reason I didn't invite you to the wedding. I went out with those girls because I was trying to feel something again, no one has made me feel like you do, Ronnie I don't want to lose you. I Love you.

\subsubsection{Phatic Function}

In the movie "The Last Song" a politeness expression appears. Phatic function also refers to the characters and their relationship with the characters as illustrated below:

Jonah : Hey dad, do you and mom ever talk about getting back together?

Dad : Jonah, your mom's about to get married so? you have dibs.

Jonah : You married her first.

The conversation between Jonah and Dad shows a phatic function. From the sentence, dad prolongs the conversation with Jonah by uttering that question to continue their conversation. The word back together in the end of sentence shows a structure of politeness.

\subsubsection{Referential Function}

The script of the movie consists of referential function as shown below.

Ronnie : Go away

Will : Ronnie, what happened? Ronnie! (Will show the respect to father of Ronnie with utterance) I'm sorry, Sir Could you tell me, what's going on?

From the conversation above it can be seen that the word "Could" shows politeness utterance addressed to Ronnie dad's.

\subsubsection{Meta-Linguistic Function}

Meta-linguistic function is used to discuss the language itself, that is, the language used while in the process of communication.

The meta-linguistic function of speech is shown in the conversation below.

Will : Could you just give it some gas, please

Ronnie : Ok, a little harder.

From the conversation it can be concluded that the positive politeness principle is still used. This can be seen from Will as Ronnie's boyfriend utterance; the word "Could" is more polite than "Can".

\subsection{Analysis of the Factors Contributing to Politeness}

The factors that influence politeness can be divided into:

\subsubsection{Age}

Age is an important factor influencing politeness; the power can also cause the interaction between two participants of different ages. (Brown and Levinson: 1987).

From the conversation between Will and Jonah, it can be seen that Will, Ronnie's boyfriend, is older than Jonah as Ronnie's brother. He addresses Jonah with special language 'Bro', meaning that Will respects Jonah. 
Will : Hello

Jonah : Don't "hello" me, I need your name, soldier.

Will : I'm Will, you are?

Jonah : I'm her roommate, the commanding officer sent me out with rations but unfortunately, it's vegetarian so personally I'd rather eat sand.

Will : Thanks for the tip bro.

The conversation above clearly shows that young people have to be politer to someone who is older. Jonah is ten years old. As a kid, he is kind when he starts talking with someone who is older than him. In the dialogue he said "Don't hello me. I need your name Soldier".

\subsubsection{Social Status}

Social status refers to rank status: low, middle and higher status. In the movie the Last Song, the social status can be seen from the main characters, Will and Ronnie.

$\begin{array}{ll}\text { George } & \text { : Hello } \\ \text { Will } & : \text { Hey George } \\ \text { Ronnie } & : \text { What are we doing? }\end{array}$ who's George? Will where are we? Grace land? wait, do you work here too? this is your house? you live here? you're rich? Will, you told me that your dad owned a brake shop?

Will : He does, he just happens to own 300 more just like it

The analysis of the conversation above is based on the factors that influence the kinds of politeness expressions used. And the status of Ronnie in the movie is as Will's girlfriend and the social status of Ronnie is lower than Will.

\subsubsection{Sex (Gender)}

According to Brown and Levinson, women show more polite expressions than men. In the movie "The Last Song" a personal conversation between Ronnie and her dad was found.
In the conversation the woman speaks more politely than men, meaning that when Ronnie talks about herself to her dad, Ronnie speaks more politely than her dad. (Brown and Levinson. 1987)

Dad : Well, a little but love is, Ronnie. crazy a little.

Ronnie : Thank you. Good night, dad.

The conversation between Ronnie and her dad above shows that Ronnie as his daughter says thank you, good night, dad. Ronnie shows her respect to choose.

\subsubsection{Education}

Education is the process by which society deliberately transmits its accumulated knowledge, skills and values from one generation to another through institutions. Education teaches people to learn how to do things and encourage them to think about what they learn. Education is also one of the factors that might influence politeness principle in the movie "The Last Song".

Conversation page 4

Jonah : Ronnie never opens any of your letters.

Dad : Really?

Jonah : Mom says to me it's because she has PMS.

Dad : Do you know what that is?

Jonah : Dad, I'm not a little kid anymore. Means "Pissed at Men Syndrome"

Dad : Yeah...

The conversation above shows that, even though it has been a long time since Jonah and his dad last met, he speaks politely to his dad.

\section{Conclusion}

According to the analysis above, it can be seen that there are a lot of positive politeness principles used by the characters in the movie "The Last Song". 


\section{Bibliography}

Holmes, Janet. (1992). An Introduction to Sociolinguistics. Pearson. Educational Limited.

Hymes, Dell. (1974). Foundations in Sociolinguistics: An Ethnographic Approach [Internet]. Philadephia: University of Pennsylvania Press.

Kousar, Shazia. (2015). Politeness Orientation in Social Hierarchies in Urdu [Internet]. Pakistan: University of Sargodha. Available from: http://jurnal.homepage.ac.id/201 4/index.php/Ijscl.net. [Accessed $27^{\text {th }}$ April 2017] 